\title{
Integration of partial resistance, plant density and use of fungicide for management of white mould in common bean
}

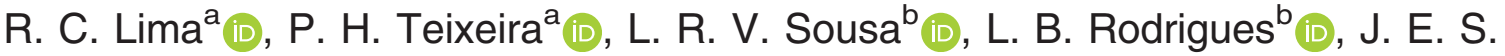 \\ Carneiro $^{\mathrm{a}}\left(\mathbb{D}\right.$, M. S. Lehner ${ }^{\mathrm{C}}$, T. J. Paula Júnior ${ }^{\mathrm{b}}$ (D) and R. F. Vieira ${ }^{\mathrm{d} *}$ (D) \\ a Departamento de Fitotecnia, Universidade Federal de Viçosa (UFV), Viçosa, MG 36570-900; 'bmpresa de Pesquisa Agropecuária de \\ Minas Gerais (Epamig), Viçosa, MG 36570-900; ' Programa de Pós-graduacão em Genética e Melhoramento, UFV, Viçosa, MG 36570- \\ 900; and ' Empresa Brasileira de Pesquisa Agropecuária/Epamig, Viçosa, MG 36570-900, Brazil
}

In-row plant densities have not been studied for common beans with type II growth habit and contrasting reactions to white mould. Advanced breeding lines with partial resistance or susceptibility to white mould were combined with 4, 7,10 or 13 plants $\mathrm{m}^{-1}$ and with or without fungicide at a constant between-row spacing of $0.5 \mathrm{~m}$ in five sprinklerirrigated field trials conducted during the autumn-winter season in Brazil. White mould pressures in the trials covered the whole range from zero to moderate/high $(46-60 \%$ of white mould severity index). In all trials, means of white mould incidence, severity and yield did not vary significantly between 7 and 13 plants $\mathrm{m}^{-1}$ for the partially resistant line, regardless of the fungicide levels. For the susceptible line, 13 plants $\mathrm{m}^{-1}$ increased white mould incidence and severity under moderate disease, regardless of the fungicide levels, and decreased yield compared with 10 plants $\mathrm{m}^{-1}$ when fungicide was applied twice under moderate/high disease pressure. For the susceptible line, 7 or 10 plants $\mathrm{m}^{-1}$ maximized yield in all trials, with or without fungicide applications. The results suggest that the current recommendation of 11-13 plants $\mathrm{m}^{-1}$ could be used for type II beans with partial resistance to white mould in either a conventional or organic system. For susceptible genotypes, $7-10$ plants $\mathrm{m}^{-1}$ seems to be the most appropriate in-row plant density. This study may improve the recommendation of in-row plant density for type II beans cultivated under white mould pressure.

Keywords: dry bean, growth habit, Phaseolus vulgaris, plant population, Sclerotinia sclerotiorum

\section{Introduction}

Brazil ranks first in common bean (Phaseolus vulgaris) production in the world. In Brazil, this grain legume is produced during the spring-summer ( $44 \%$ of total), summer-autumn $(28 \%)$ and autumn-winter $(28 \%)$ seasons (Conab, 2018). White mould (WM), caused by the fungus Sclerotinia sclerotiorum, occurs in the three growing seasons, but this disease is more severe during the autumn-winter season due to moderate temperature and wet conditions provided by sprinkler irrigation. The State of Minas Gerais, southeastern Brazil, ranks first in common bean production during the autumn-winter season with an annual production of 184000 tonnes and an average grain yield of $2618 \mathrm{~kg} \mathrm{ha}^{-1}$ (Conab, 2018).

In the irrigated areas of common bean in Minas Gerais, at least two applications of specific fungicides for WM management are generally used by farmers. In this state, two applications of fluazinam increased the yield

*E-mail: rfvieira@epamig.br

Published online 3 January 2019 of a semiprostrate type III growth habit cultivar under severe WM pressure by 2.2-fold (Vieira et al., 2010). In addition to fungicide applications, biological control, lower plant population, less irrigation and nitrogen fertilization, and genetic resistance are useful in managing WM (Miklas et al., 2013; Schwartz \& Singh, 2013).

Common bean resistance to WM is partial and is conditioned by both avoidance and physiological mechanisms. Avoidance mechanisms are related to plant morphological and phenological traits that create an unfavourable microclimate for the pathogen infection and disease progress (Pascual et al., 2010). Avoidance mechanisms are fully expressed in the field and include upright and open plant canopy (Hoyos-Villegas et al., 2015). Physiological mechanisms are generally detected in the greenhouse and are related to plant defence mechanisms that limit infection or spread of the pathogen in host tissue (Pascual et al., 2010).

Most of the cultivars used in Brazil belong to the carioca market class (beige with brown stripes). These cultivars have indeterminate type II (such as cv. BRS Estilo), semiprostrate type III (such as Pérola) or prostrate type III (such as BRSMG Majestoso and BRSMG Madrepérola) growth habits. These cultivars are 
moderately resistant (Pérola and Estilo) or susceptible (Majestoso, Madrepérola) to WM in the field (Lima et al., 2015; Teixeira et al., 2018). Since 2008, common bean advanced breeding lines have been screened for partial resistance to WM. The lines screened have exhibited higher levels of WM resistance in the field than Pérola and Estilo, the cultivars most planted in Brazil. CNFC 10720 is among those lines. This line exhibited low physiological resistance (Lima et al., 2013), but it was among those that exhibited field resistance to WM and had the highest yields under WM pressure (Lima et al., 2015; Teixeira et al., 2018). The results of these studies seem to indicate that partial resistance of CNFC 10720 is heavily associated with avoidance mechanisms.

Currently, for common bean areas free of S. sclerotiorum in the southeastern and central region of Brazil, the recommendation is between-row spacing of $0.40-0.50 \mathrm{~m}$ for type II and $0.45-0.55 \mathrm{~m}$ for type III cultivars, with 11-13 and 8-10 plants $\mathrm{m}^{-1}$, respectively (Ramalho et al., 2014). The microclimate within the bean canopy may be modified by increasing between-row spacing and/ or decreasing in-row plant density (IRPD). An open canopy at flowering creates a microclimate that is less favourable for WM development (Miklas et al., 2013). In Brazil, by decreasing IRPD from 16 or 15 to 4 or 5 plants $\mathrm{m}^{-1}$, WM incidence and severity decreased (Paula Júnior et al., 2009; Vieira et al., 2010, 2012) and seed yield increased in the semiprostrate type III growth habit cultivar Pérola cultivated under moderate/high or high disease pressure (Vieira et al., 2010).

In addition to agronomic practices, type II growth habit contributes to an open canopy that is more resistant to lodging (Miklas et al., 2014), although not all type II beans avoid WM equally (Saindon et al., 1995; Schwartz \& Singh, 2013). In Canada, IRPD (from 7.7-10 to 20-25 plants $\mathrm{m}^{-1}$ ) combined with the between-row spacing of $0.30,0.45$ or $0.60 \mathrm{~m}$ did not affect WM development for type II beans not genetically resistant to WM (Saindon et al., 1993), or the response was inconsistent when 5.7-13.8 plants $\mathrm{m}^{-1}$ were assessed with the constant between-row spacing of $0.23 \mathrm{~m}$ (Saindon et al., 1995). These studies showed that type II beans may be grown at higher IRPD than type III beans without greatly increasing WM. However, the effects of IRPD on WM development for type
II plants have not been studied for beans with a contrasting reaction to WM.

The objective of this study was to determine the effects of IRPD combined with fungicide levels on WM disease and grain yield of two common beans with type II growth habit contrasting in their reaction to this disease in the field. The hypothesis was that beans with partial resistance to $\mathrm{WM}$ in the field can be grown with the currently recommended 11-13 plants $\mathrm{m}^{-1}$ without greatly increasing disease and with no decrease in yield, but a lower IRPD is more appropriate for beans susceptible to WM.

\section{Material and methods}

\section{Experimental locations, climate and soil properties}

Five common bean trials were conducted in fields naturally infested with S. sclerotiorum during the autumn-winter season in three districts of the State of Minas Gerais, Brazil. Details regarding sowing date and sites are described in Table 1. In general, for over 20 years, the soils have been cultivated with maize (Zea mays) during the spring-summer season and usually with common bean during the autumn-winter season. According to Köppen's classification, the climate in these districts is Cwa: subtropical warm with dry winter (Alvares et al., 2014).

\section{Treatments, experimental design, plot and crop management}

Treatments were a combination of IRPD $(4,7,10$ or 13 plants $\mathrm{m}^{-1}$ ), advanced breeding lines (CNFC 10720 or VC 6) and fungicide to manage WM (with or without). Rows were spaced $0.5 \mathrm{~m}$ apart. Seeds were manually sown with $50 \%$ more seeds than planned plant densities and subsequent thinning at V3 developmental stage (first trifoliate leaf) to nearly uniform distances between plants. Both lines have low physiological resistance to WM (Lehner et al., 2011; Lima et al., 2013), but unlike VC 6, CNFC 10720 seems to exhibit avoidance mechanisms (Lima et al., 2015; Teixeira et al., 2018). Both lines have indeterminate type II growth habit and similar life cycle duration, and belong to the carioca market class. The fungicide Frowncide SC $(50 \%$ fluazinam; Ishihara Brasil Defensivos Agrícolas) at $0.625 \mathrm{~L} \mathrm{ha}^{-1}$ was sprayed using a $\mathrm{CO}_{2}$ pressurized backpack $(207 \mathrm{kPa})$ with a bar of two cone nozzles (Teejet 110.03), spaced $0.5 \mathrm{~m}$ apart, at a volume of $700 \mathrm{~L} \mathrm{ha}^{-1}$. Fungicide was applied when $20-50 \%$ of plants had at least one open flower and was repeated 10 days later.

Table 1 Details of experimental sites in three districts of the State of Minas Gerais, Brazil.

\begin{tabular}{|c|c|c|c|c|c|c|c|}
\hline \multirow[b]{2}{*}{ District $^{a}$} & \multirow[b]{2}{*}{ Harvest year } & \multirow[b]{2}{*}{ Sowing data } & \multirow[b]{2}{*}{ History of white mould (years) } & \multicolumn{4}{|c|}{ Soil characteristic } \\
\hline & & & & $\mathrm{pH}_{\mathrm{H} 2 \mathrm{O}}(1: 2.5)$ & Clay (\%) & Silt (\%) & $\overline{\text { Sand }(\%)}$ \\
\hline Coimbra & 2011 & 4 May & 2 & 5.0 & 56 & 19 & 25 \\
\hline \multirow[t]{3}{*}{ Viçosa } & 2011 & 10 May & 18 & 5.3 & 53 & 24 & 23 \\
\hline & 2012 & 8 May & & & & & \\
\hline & 2013 & 30 April & & & & & \\
\hline Oratórios & 2013 & 26 April & 11 & 5.3 & 31 & 44 & 25 \\
\hline
\end{tabular}

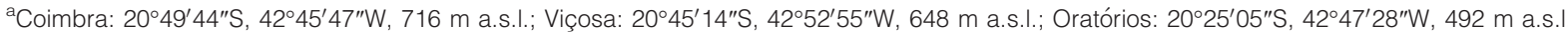

${ }^{b}$ Number of years before 2011 when white mould was first observed in the site. 
The statistical design was a randomized complete block with five replicates in Coimbra and four replicates in the other trials. Each plot consisted of five $3 \mathrm{~m}$-long rows. Adjacent plots were separated from each other by $1 \mathrm{~m}$.

One month before sowing, Roundup (48\% glyphosate; Helm do Brasil Mercantil) at $3 \mathrm{~L} \mathrm{ha}^{-1}$ was applied over the weeds. Between 5 and 8 days before sowing, the soil was discploughed to a depth of approximately $0.20 \mathrm{~m}$ followed by heavy-disc harrowing twice. Inorganic fertilizers (sources of nitrogen, phosphorus, potassium and molybdenum) were used targeting yields above $2500 \mathrm{~kg} \mathrm{ha}^{-1}$ (Ramalho et al., 2014). Irrigation was provided with sprinklers fixed $1.5 \mathrm{~m}$ above ground level at 2-day intervals from sowing to seedling emergence. From seedling emergence to harvest, plants were irrigated once a week with approximately $40 \mathrm{~mm}$ of water. Weeds were controlled by post-emergence herbicides, and insects were controlled with two or three sprays of insecticides during the vegetative stage of the plants. Amistar WG $150 \%$ azoxystrobin; Syngenta) at $0.1 \mathrm{~kg} \mathrm{ha}^{-1}$ was sprayed twice at V4 growth stage to reduce the effects of foliar diseases such as angular leaf spot (Phaeoisariopsis griseola) on bean yield. The last application of azoxystrobin was made between 8 and 11 days before the onset of flowering.

\section{Assessment data}

Canopy closure, foliar disease severity, plant population and 100-seed weight

Canopy closure was evaluated at R6 growth stage (flowering) by observing each plot from one end of the plot (looking down the rows) and visually estimating the proportion of soil surface visible between the rows $(100 \%$ represents complete ground cover) (Kane \& Grabau, 1992). For foliar diseases, severity was evaluated at R7 growth stage (pod development) on a 1-9 scale, in which $1=$ no visible symptoms, $3=$ low, $5=$ moderate, $7=$ high, $9=$ very high $(\operatorname{van}$ Schoonhoven \& Pastor-Corrales, 1987). Final plant population was estimated by counting the number of plants in the three central rows of each plot. Seeds with $13 \%$ moisture were used to estimate the 100 -seed weight.

White mould incidence and severity, and grain yield The three central rows of each plot with an area of $4.5 \mathrm{~m}^{2}$ were used for data collection. Plants harvested in each plot were rated individually for WM incidence (WMI) and WM severity by means of a quarter scale (Hall \& Phillips, 1996), in which $0=$ no symptoms, $1=1-25 \%$ of the plant with symptoms, $2=26-50 \%$ of the plant with symptoms, $3=51-75 \%$ of the plant with symptoms and $4=76-100 \%$ of the plant with symptoms. WM severity index (WMSI) was calculated for each plot on a percentage basis by the following formula (Kolkman \& Kelly, 2002):

$$
\text { WMSI }=\frac{\sum(\text { score assigned to each plant })}{4 \times(\text { total number of assessed plants })} \times 100
$$

WM pressure was considered low when the unsprayed plants of the susceptible line exhibited WMI $\leq 25 \%$ or WMSI $\leq 15 \%$; low/moderate, $26-45 \%$ of WMI or $16-30 \%$ of WMSI; moderate, $46-65 \%$ of WMI or $31-45 \%$ of WMSI; moderate/high, 66$85 \%$ of WMI or $46-60 \%$ WMSI; and high, $\geq 85 \%$ of WMI or $\geq 60 \%$ of WMSI.

Plants from each plot were threshed together and grain yields were estimated in $\mathrm{g}$, which were then converted to $\mathrm{kg} \mathrm{ha}^{-1}$ at $13 \%$ moisture.

\section{Statistical analysis}

The data were analysed using the software program SISTEMA PARA ANÁLISES ESTATí́sTICAS (SAEg; Ribeiro Júnior, 2001). Each trial was analysed individually because the WM pressure varied among trials. A three-way ANOVA was used to analyse the effects of IRPD $\left(4,7,10\right.$ or 13 plants $\left.\mathrm{m}^{-1}\right)$, line (CNFC 10720 or VC 6) and fungicide (with or without). The fixed factors were IRPD, line, fungicide, and their interactions. The random factor was block. A cross-site analysis was also carried out for the four trials where WM occurred. In this case, trial (site-year) was treated as a fixed factor. Means of variables affected by line or fungicide use were compared by $F$-test. Duncan's test $(P<0.05)$ was used to compare means of variables affected by IRPD.

\section{Results}

\section{Canopy closure, plant population, general diseases, mean yield and 100-seed weight}

In all trials, plants of the WM-resistant line showed less lodging and were taller than those of the WM-susceptible line. Results of the five trials averaged across line and fluazinam showed that canopy closure at flowering was reduced by $5 \%\left(10\right.$ plants $\left.\mathrm{m}^{-1}\right), 13 \%$ (7 plants $\left.\mathrm{m}^{-1}\right)$ and $27 \%$ (4 plants $\mathrm{m}^{-1}$ ) compared with canopy closure at 13 plants $\mathrm{m}^{-1}$ (Fig. 1). The final plant populations were close to the planned plant population (Table 2). WM was absent in Coimbra, low in Viçosa (2011), low/ moderate in Viçosa (2012), moderate in Viçosa (2013), and moderate/high in Oratórios (2013). Angular leaf spot was observed at R7 growth stage of the common bean lines in Coimbra and Viçosa (2011, 2012), with low, moderate and low/moderate severity, respectively. In the fluazinam-sprayed plots there were relatively fewer angular leaf spot symptoms on the plants. Delayed senescence of plants was not observed in the fluazinamsprayed plots when WM pressure was absent (Coimbra) or at low levels (Viçosa, 2011).

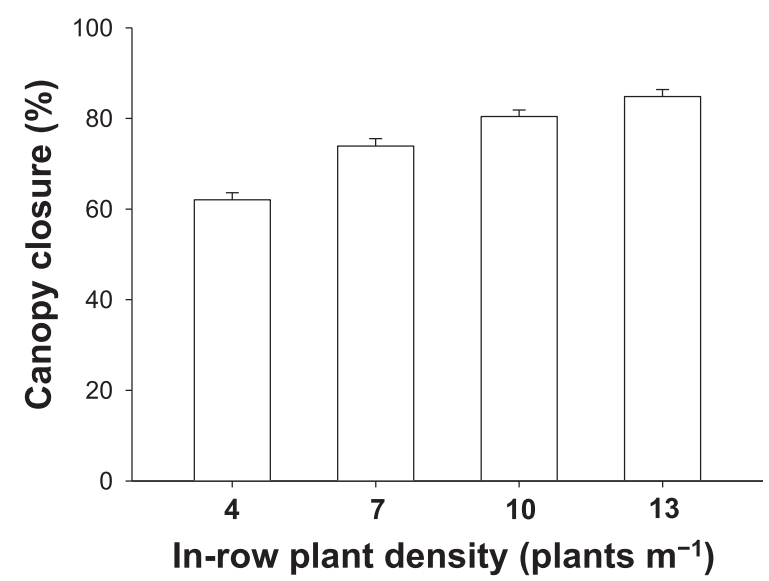

Figure 1 Average effect of in-row plant density on the common bean canopy closure (100\% representing complete ground cover) at flowering over five trials $(n=84)$. Bars represent standard error of mean. 
Table 2 Plant population in the five trials conducted in three districts of the State of Minas Gerais, Brazil.

\begin{tabular}{|c|c|c|c|c|c|}
\hline \multirow{2}{*}{$\begin{array}{l}\text { Planned } \\
\text { plant population } \\
\text { per hectare } \\
(\times 1000)\end{array}$} & \multicolumn{5}{|c|}{ Final plant population per hectare $(\times 1000)$} \\
\hline & Coimbra & $\begin{array}{l}\text { Viçosa } \\
\text { (2011) }\end{array}$ & $\begin{array}{l}\text { Viçosa } \\
\text { (2012) }\end{array}$ & $\begin{array}{l}\text { Viçosa } \\
\text { (2013) }\end{array}$ & Oratórios \\
\hline 80 & 79.7 & 80.6 & 80.6 & 83.1 & 81.8 \\
\hline 140 & 139.3 & 137.1 & 137.1 & 137.8 & 140.7 \\
\hline 200 & 210.0 & 211.2 & 192.8 & 196.9 & 197.1 \\
\hline 260 & 270.7 & 270.8 & 249.4 & 250.4 & 257.8 \\
\hline
\end{tabular}

Mean grain yield in each of the five trials ranged from 1923 to $3031 \mathrm{~kg} \mathrm{ha}^{-1}$. Averaged across line and IRPD, fluazinam applications increased yield by $16 \%$ in Coimbra, $13 \%$ in Viçosa (2011), 20\% in Viçosa (2012), 25\% in Viçosa (2013) and 57\% in Oratórios. Fluazinam significantly increased 100-seed weight in all trials, except in Coimbra (data not shown). Averaged across line and fluazinam, IRPD affected $(P<0.001)$ 100-seed weight in Viçosa (2012) and Viçosa (2013). In these two trials, 4 plants $\mathrm{m}^{-1}$ increased 100 -seed weight compared with the other IRPDs, which had similar means. On the average of the five trials across line and fungicide, 100-seed weight was 24.5, 24.2, 23.7 and $23.8 \mathrm{~g}$ for 4, 7, 10 and 13 plants $\mathrm{m}^{-1}$, respectively. Averaged across IRPD and fungicide, the susceptible line had greater 100-seed weight than the resistant line in all trials, except in Oratórios, where difference between lines was nonsignificant.

\section{White mould incidence and severity, and grain yield}

\section{Coimbra trial}

In the absence of WM symptoms on plants, the effect of each single factor on yield was significant, but interactions were nonsignificant (Table 3). Averaged across IRPD and fungicide, the WM-susceptible line yielded $11 \%$ more than the resistant line $\left(2020 \mathrm{~kg} \mathrm{ha}^{-1}\right.$ vs $\left.1826 \mathrm{~kg} \mathrm{ha}^{-1}\right)$. Averaged across line and fluazinam, 4 plants $\mathrm{m}^{-1}$ reduced yield by $14 \%$ compared with 13 plants $\mathrm{m}^{-1}$ (Fig. 2). Averaged across IRPD and line, plants sprayed with fluazinam yielded more than those unsprayed (2066 kg ha ${ }^{-1}$ vs $1781 \mathrm{~kg} \mathrm{ha}^{-1}$ ).

\section{Viçosa trials}

In 2011, under low WM pressure, line $\times$ fungicide interaction was very highly significant for WMI and WMSI, and IRPD $\times$ fungicide interaction was significant for yield (Table 3). Fluazinam decreased WMI by approximately 3.3-fold for the two lines (Fig. 3a), but it decreased WMSI by 2.8-fold for the WM-resistant line and by 4.4-fold for the susceptible line (Fig. 3b). Averaged across line, 4 plants $\mathrm{m}^{-1}$ reduced yield by $31 \%$ relative to 13 plants $\mathrm{m}^{-1}$ when fluazinam was applied (Fig. 3c). Without fluazinam, difference in yield between 4 and 13 plants $\mathrm{m}^{-1}$ was $21 \%$. Difference in yield between the susceptible and the resistant line $\left(2785 \mathrm{~kg} \mathrm{ha}^{-1}\right.$ vs $\left.2651 \mathrm{~kg} \mathrm{ha}^{-1}\right)$ was marginally significant.
Table 3 Levels of significance for the fixed effects common bean line (L), in-row plant density (IRPD), fungicide (F) and interactions among these factors on white mould incidence (WMI), white mould severity index (WMSI) and grain yield in five trials conducted in three districts of the State of Minas Gerais, Brazil.

\begin{tabular}{|c|c|c|c|c|c|}
\hline $\begin{array}{l}\text { Trial (white } \\
\text { mould } \\
\text { pressure) }\end{array}$ & Fixed effects & d.f. & WMI & WMSI & Yield \\
\hline \multirow{7}{*}{$\begin{array}{l}\text { Coimbra } 2011 \\
\text { (absent) }\end{array}$} & $\mathrm{L}$ & 1 & - & - & 0.001 \\
\hline & IRPD & 3 & - & - & 0.005 \\
\hline & $\mathrm{F}$ & 1 & - & - & $<0.001$ \\
\hline & $L \times I R P D$ & 3 & - & - & 0.144 \\
\hline & $L \times F$ & 1 & - & - & 0.519 \\
\hline & $\mathrm{IRPD} \times \mathrm{F}$ & 3 & - & - & 0.445 \\
\hline & $L \times I R P D \times F$ & 3 & - & - & 0.082 \\
\hline \multirow[t]{7}{*}{ Viçosa 2011 (low) } & $\mathrm{L}$ & 1 & $<0.001$ & $<0.001$ & 0.065 \\
\hline & IRPD & 3 & $<0.212$ & 0.110 & $<0.001$ \\
\hline & $\mathrm{F}$ & 1 & $<0.001$ & $<0.001$ & $<0.001$ \\
\hline & $L \times I R P D$ & 3 & 0.882 & 0.545 & 0.271 \\
\hline & $L \times F$ & 1 & $<0.001$ & $<0.001$ & 0.274 \\
\hline & $\mathrm{IRPD} \times \mathrm{F}$ & 3 & 0.698 & 0.840 & 0.045 \\
\hline & $L \times I R P D \times F$ & 3 & 0.657 & 0.025 & 0.484 \\
\hline \multirow{7}{*}{$\begin{array}{l}\text { Viçosa } 2012 \\
\text { (low/moderate) }\end{array}$} & $L$ & 1 & 0.002 & $<0.001$ & 0.492 \\
\hline & IRPD & 3 & 0.439 & 0.198 & $<0.001$ \\
\hline & $\mathrm{F}$ & 1 & $<0.001$ & $<0.001$ & $<0.001$ \\
\hline & $L \times I R P D$ & 3 & 0.332 & 0.449 & 0.651 \\
\hline & $L \times F$ & 1 & 0.102 & 0.029 & 0.657 \\
\hline & $\mathrm{IRPD} \times \mathrm{F}$ & 3 & 0.365 & 0.288 & 0.439 \\
\hline & $L \times I R P D \times F$ & 3 & 0.569 & 0.740 & 0.761 \\
\hline \multirow{7}{*}{$\begin{array}{c}\text { Viçosa } 2013 \\
\text { (moderate) }\end{array}$} & $L$ & 1 & $<0.001$ & $<0.001$ & $<0.001$ \\
\hline & IRPD & 3 & 0.006 & $<0.001$ & 0.094 \\
\hline & $\mathrm{F}$ & 1 & $<0.001$ & $<0.001$ & $<0.001$ \\
\hline & $L \times I R P D$ & 3 & 0.062 & 0.002 & 0.420 \\
\hline & $L \times F$ & 1 & $<0.001$ & $<0.001$ & 0.002 \\
\hline & $\mathrm{IRPD} \times \mathrm{F}$ & 3 & 0.575 & 0.176 & 0.326 \\
\hline & $L \times \operatorname{IRPD} \times F$ & 3 & 0.761 & 0.353 & 0.618 \\
\hline \multirow{7}{*}{$\begin{array}{l}\text { Oratórios } 2013 \\
\text { (moderate/high) }\end{array}$} & $\mathrm{L}$ & 1 & $<0.001$ & $<0.001$ & 0.086 \\
\hline & IRPD & 3 & 0.804 & 0.291 & 0.249 \\
\hline & $\mathrm{F}$ & 1 & $<0.001$ & $<0.001$ & $<0.001$ \\
\hline & $L \times I R P D$ & 3 & 0.782 & 0.575 & 0.190 \\
\hline & $L \times F$ & 1 & 0.203 & 0.753 & $<0.001$ \\
\hline & $\mathrm{IRPD} \times \mathrm{F}$ & 3 & 0.140 & 0.534 & 0.346 \\
\hline & $L \times I R P D \times F$ & 3 & 0.782 & 0.484 & 0.036 \\
\hline
\end{tabular}

In 2012, under low/moderate WM pressure, effect of line on WMI was highly significant, and effect of fungicide on WMI was very highly significant (Table 3). Averaged across IRPD and fungicide, the WM-susceptible line exhibited higher WMI than the resistant line $(27 \%$ vs $15 \%)$. There was a significant line $\times$ fungicide interaction for WMSI: fluazinam decreased WMSI by 1.9-fold for the resistant line and by 2.6-fold for the susceptible line (Fig. 4). Effect of either IRPD or fungicide on yield was very highly significant. Yield at 4 plants $\mathrm{m}^{-1}\left(2538 \mathrm{~kg} \mathrm{ha}^{-1}\right)$ was lower than yields at higher IRPDs, which ranged from 2872 to $3092 \mathrm{~kg} \mathrm{ha}^{-1}$. Plants sprayed with fluazinam yielded more than those unsprayed $\left(3150 \mathrm{~kg} \mathrm{ha}^{-1}\right.$ vs $\left.2618 \mathrm{~kg} \mathrm{ha}^{-1}\right)$. Line did not affect yield significantly. 


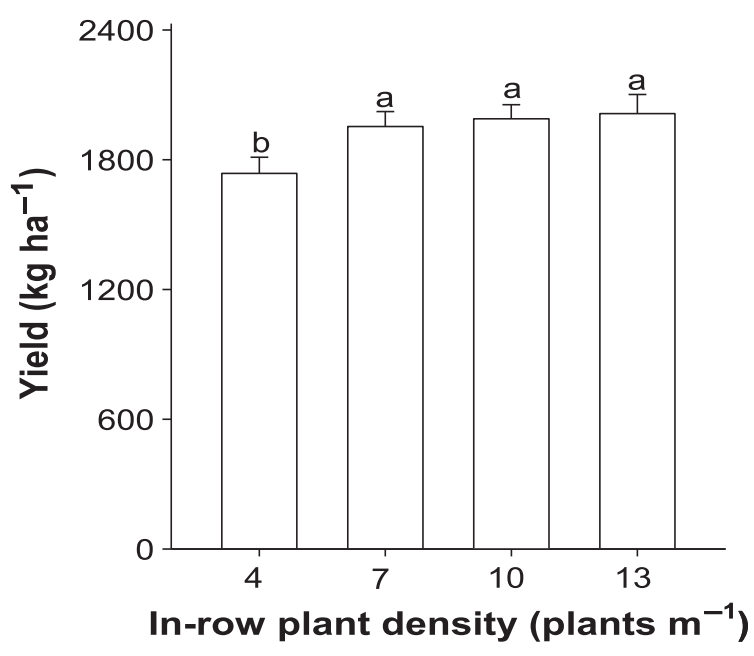

Figure 2 Effect of in-row plant density on the common bean yield averaged across line and fungicide $(n=16)$ when no symptoms of white mould (Sclerotinia sclerotiorum) in the plants were observed in Coimbra, 2011. Bars represent standard error of mean.

In 2013, under moderate WM pressure, line $\times$ IRPD interaction was marginally significant for WMI and highly significant for WMSI (Table 3). Averaged across fungicide, IRPD neither affected WMI (Fig. 5a) nor WMSI (Fig. 5b) for the resistant line. However, 13 plants $\mathrm{m}^{-1}$ increased WMI and WMSI relative to the other IRPDs for the susceptible line. In addition, for the susceptible line, 10 plants $\mathrm{m}^{-1}$ exhibited higher WMSI than either 4 or 7 plants $\mathrm{m}^{-1}$. Line $\times$ fungicide interaction was very highly significant for WMI and WMSI and highly significant for yield. Fluazinam reduced WMI by 3.1-fold for the WM-resistant line and by 2.3-fold for the susceptible line (Fig. 5c), and reduced WMSI by 4.4and 3.5-fold, respectively (Fig. 5d). Averaged across IRPD, plants sprayed with fluazinam yielded more than those unsprayed, especially for the susceptible line (Fig. 5e).

\section{Oratórios trial}

Under moderate/high WM pressure, effects of either line or fungicide on WMI and WMSI were very highly significant (Table 3). Averaged across IRPD and fungicide, WMI was $62 \%$ for the susceptible line and $48 \%$ for the resistant line and WMSI was $48 \%$ and $33 \%$, respectively. Averaged across line and IRPD, fluazinam-sprayed plants had $39 \%$ of WMI and $27 \%$ of WMSI. Without fluazinam, these values were $71 \%$ and $54 \%$, respectively. IRPD $\times$ line $\times$ fungicide interaction was significant for yield. For the resistant line sprayed with fluazinam, 4 plants $\mathrm{m}^{-1}$ yielded $19 \%$ less than the mean yields of the other IRPDs (Fig. 6). However, for the susceptible line sprayed with fluazinam, 13 plants $\mathrm{m}^{-1}$ yielded $15 \%$ less than yield at 10 plants $\mathrm{m}^{-1}$, which did not differ significantly from either 4 or 7 plants $\mathrm{m}^{-1}$. When unsprayed, IRPD did not affect yield significantly for the WMresistant line or for the susceptible line.

\section{Cross-site analysis for the four trials where white mould occurred}

The interactions IRPD $\times$ line, IRPD $\times$ fungicide and IRPD $\times$ line $\times$ fungicide were not significant $(P>0.05)$ for WMI, WMSI and yield (Table S1). However, the line $\times$ fungicide interaction was significant $(P<0.001)$ for these three dependent variables. The partially resistant line had approximately one half of the mean values for WMI (Fig. 7a) and WMSI (Fig. 7b) in comparison with the susceptible line, regardless of the fungicide levels. Fungicide decreased WMI and WMSI by between 2 - and 2.5-fold for the two lines. Fungicide applications increased yield by $22 \%$ for the WM-resistant line and by $35 \%$ for the susceptible line (Fig. 7c). IRPD significantly affected $(P<0.001)$ WMSI and yield. Both 4 and 7 plants $\mathrm{m}^{-1}$ reduced the WMSI in comparison with either 10 or 13 plants $\mathrm{m}^{-1}$ (Fig. $7 \mathrm{~d}$ ), but common bean at 4 plants $\mathrm{m}^{-1}$ yielded $15 \%$ less than the average yield of 10 and 13 plants $\mathrm{m}^{-1}$ (Fig. 7e). However, IRPD $\times$ trial interaction was very highly significant for WMSI and yield. Thus, the effects of IRPD on WMSI and yield were calculated individually for each trial as previously presented.

\section{Discussion}

It was hypothesized that type II beans with partial field resistance to WM could be grown with the currently recommended 11-13 plants $\mathrm{m}^{-1}$ (Ramalho et al., 2014), but for those susceptible to WM, a lower IRPD was more appropriate. To test this hypothesis, five irrigated trials were conducted in soils naturally infested with S. sclerotiorum using either a line that was partially resistant or susceptible to WM associated with 4, 7, 10 or 13 plants $\mathrm{m}^{-1}$, with or without use of fluazinam.

The assumption that line CNFC 10720 has partial resistance to WM is supported by the following results: (i) on an average of four trials, means of WMI and WMSI in plants of the WM-resistant line were almost one-half of those of the susceptible line; (ii) on an average of four trials, fungicide increased the yield of the susceptible line more effectively than the yield of the resistant line (35\% vs $22 \%$ ); and (iii) plants of the resistant line only had higher yield than those of the susceptible line when WM pressure was moderate or moderate/ high. These results are in agreement with those of Miklas et al. (2013), although these authors considered partially resistant lines as those with both physiological and avoidance mechanisms, and susceptible lines as those with the potential of WM avoidance. Because both breeding lines used in this study have low physiological resistance (Lehner et al., 2011; Lima et al., 2013), the partial resistance to WM of the line CNFC 10720 appears to be heavily associated with avoidance mechanisms. In fact, this line had taller plants and was more lodging-resistant than the susceptible line VC 6 in the current work. A reduction in plant height and an increase in lodging create a favourable microclimate for 

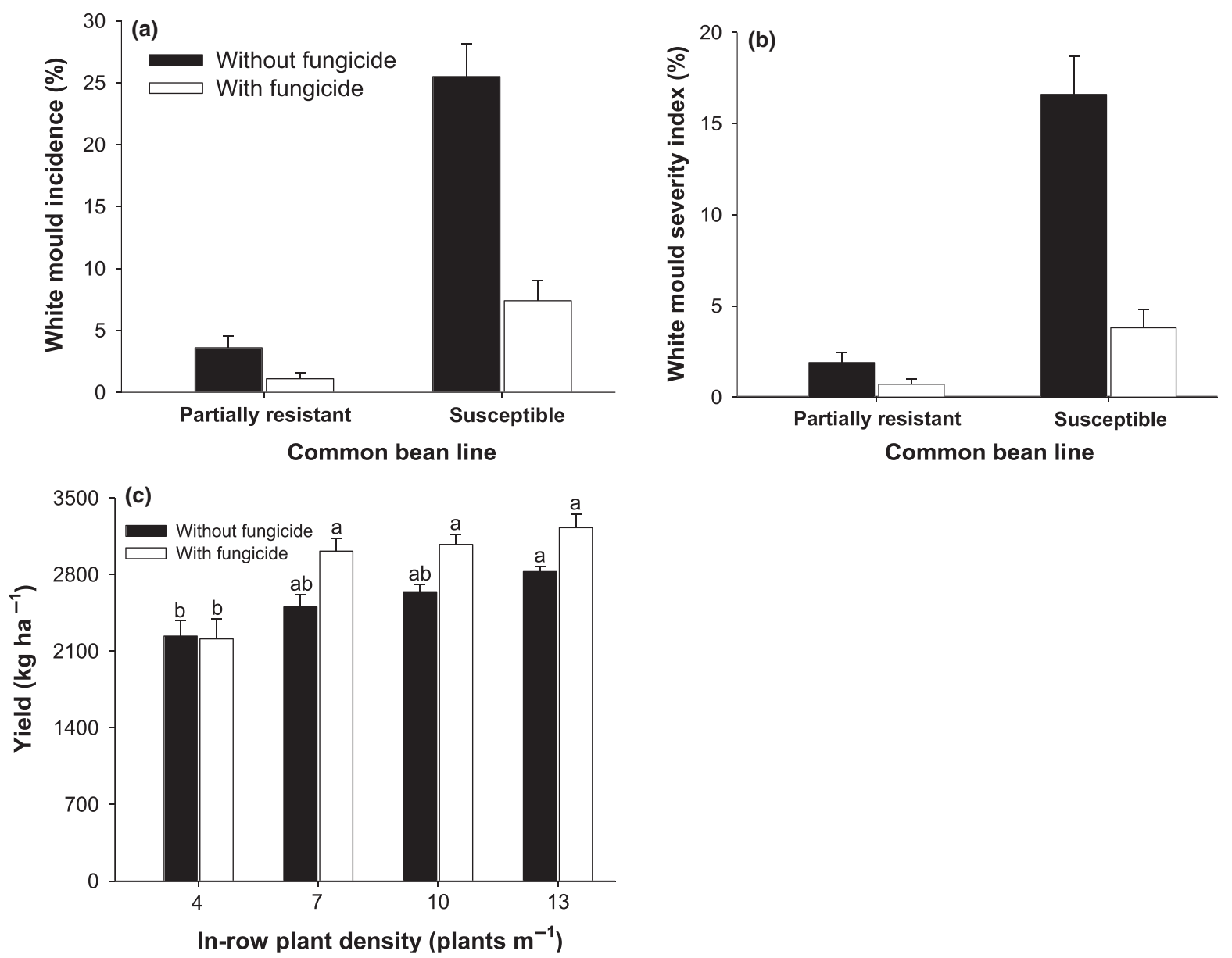

Figure 3 Common bean line (partially resistant $=$ CNFC 10720, susceptible $=$ VC 6) $\times$ fungicide interaction on (a) white mould (Sclerotinia sclerotiorum) incidence, and (b) white mould severity index averaged across in-row plant density ( $n=16$ ), in Viçosa, 2011, when white mould pressure was low. In-row plant density $\times$ fungicide interaction on yield averaged across line $(n=8)$ is presented in (c). In each fungicide level of (c), means with the same letter do not differ significantly by Duncan's test at $5 \%$ level. Error bars represent standard error of the mean.

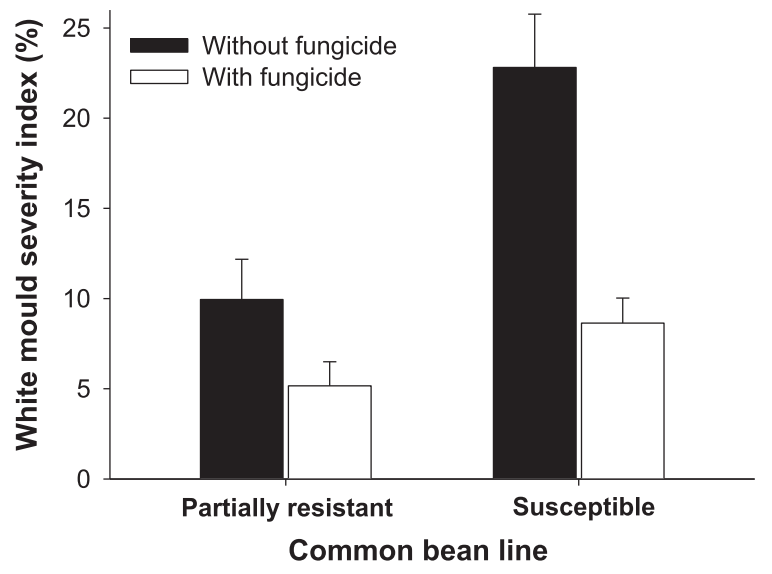

Figure 4 Common bean line (partially resistant $=$ CNFC 10720, susceptible $=$ VC 6) $\times$ fungicide interaction on white mould (Sclerotinia sclerotiorum) severity index averaged across in-row plant density in Viçosa, 2012, when white mould pressure was low/moderate. Error bars represent the standard error of the mean $(n=16)$.
WM development (Kolkman \& Kelly, 2002; Miklas et al., 2013; Hoyos-Villegas et al., 2015).

The Andean line A 195 is a known source of partial resistance to WM, and both physiological and avoidance mechanisms contribute to its field resistance (Singh et al., 2007; Viteri et al., 2015). However, this line exhibited similar or lower field resistance to WM than some Brazilian lines of Mesoamerican origin with low physiological mechanisms (Lima et al., 2015; Teixeira et al., 2018), indicating that the physiological mechanisms could be less important than WM avoidance in Brazilian conditions. Combining physiological with avoidance mechanisms is the most viable strategy to ensure adequate levels of field resistance to WM in the more humid Midwest of the USA (Ender \& Kelly, 2005). However, in southeastern and central Brazil, where the climate conditions during the autumn-winter season are very dry (Alvares et al., 2014), avoidance to WM appears to be enough for adequate levels of partial resistance in the field for some lines. Hence, resistance to lodging and a 
(a)
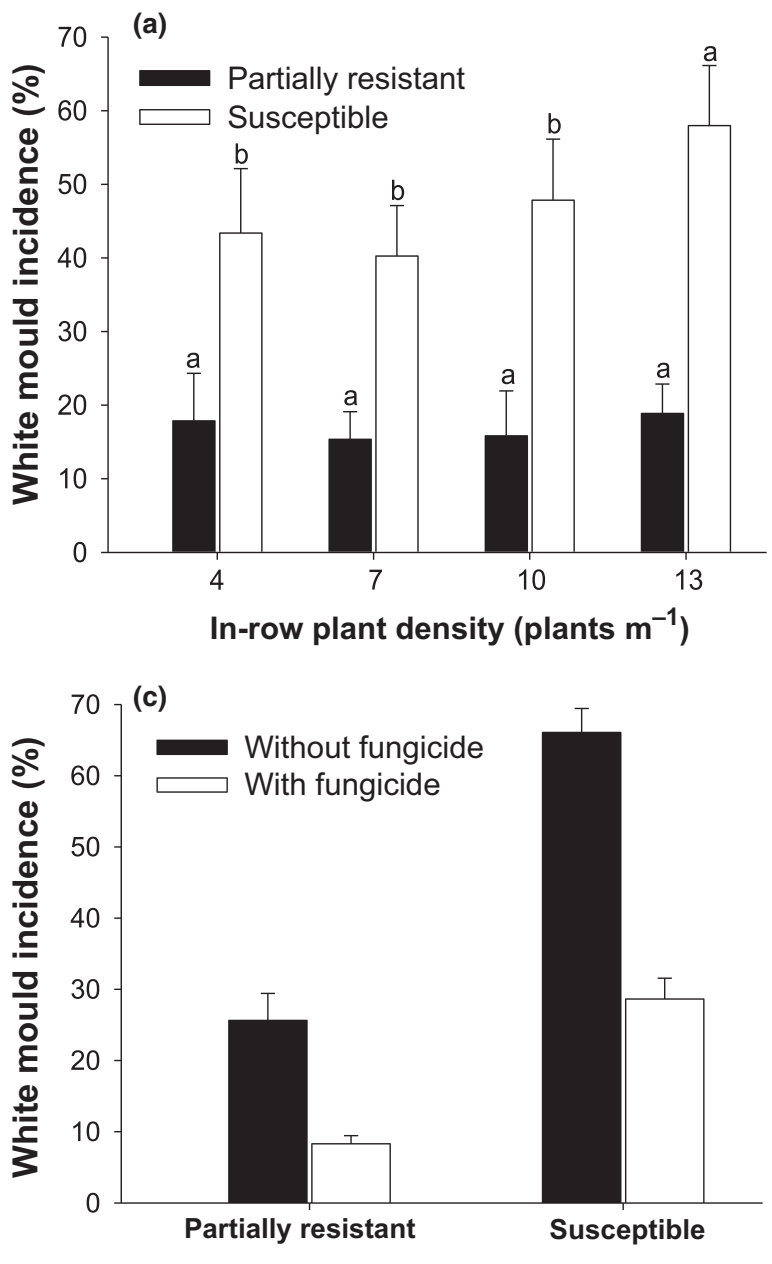

Common bean line

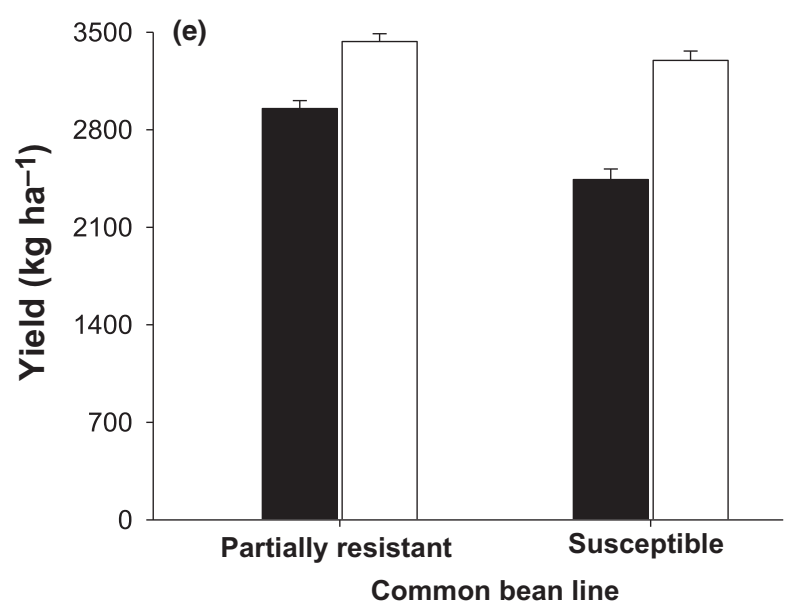

(b)

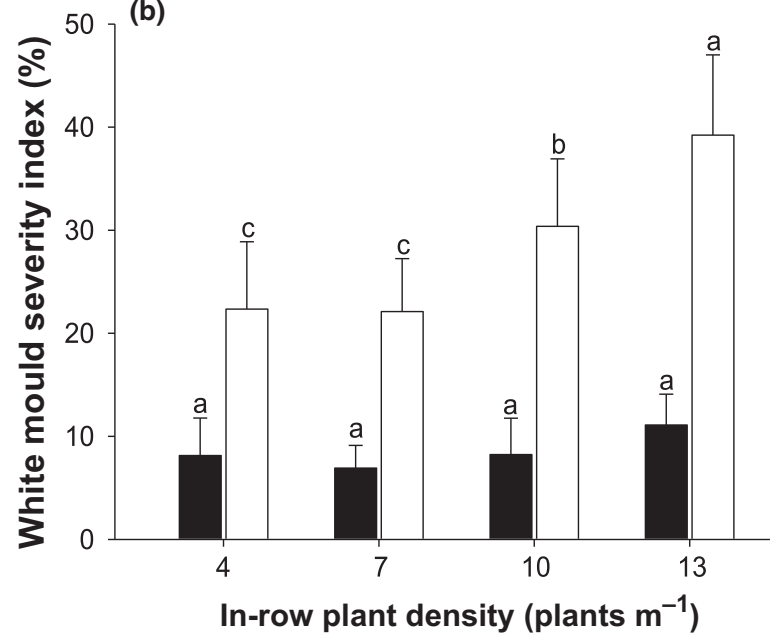

(d)

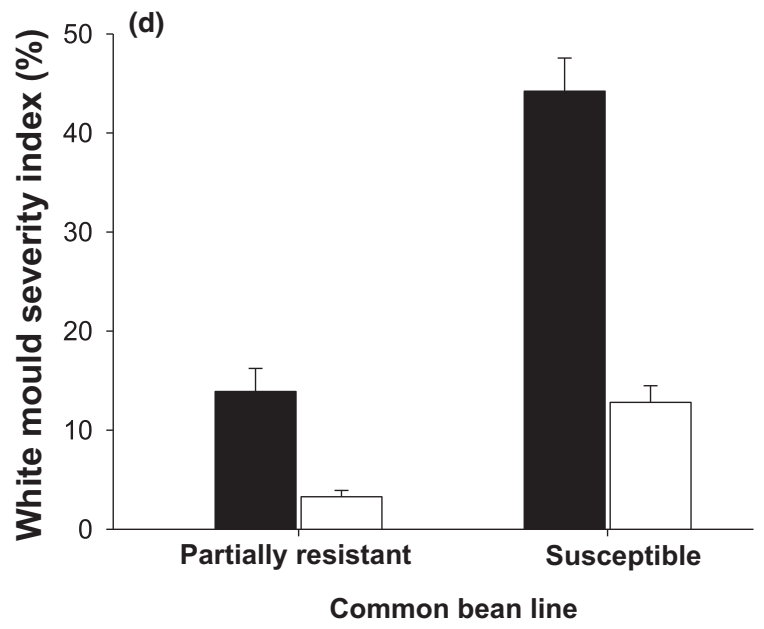

Figure 5 Common bean line (partially resistant $=$ CNFC 10720, susceptible $=$ VC 6) $\times$ in-row plant density interaction on (a) white mould (Sclerotinia sclerotiorum) incidence (WMI) and (b) white mould severity index (WMSI) averaged across fungicide $(n=8)$, in Viçosa, 2013, when white mould pressure was moderate. In (a) and (b), means with the same letter for each common bean line did not differ significantly by Duncan's test at $5 \%$ level. Line $\times$ fungicide interaction on (c) WMI and (d) WMSI averaged across in-row plant density $(n=16)$. Line $\times$ fungicide interaction on (e) yield averaged across in-row plant density $(n=16)$. Error bars represent standard error of the mean. 


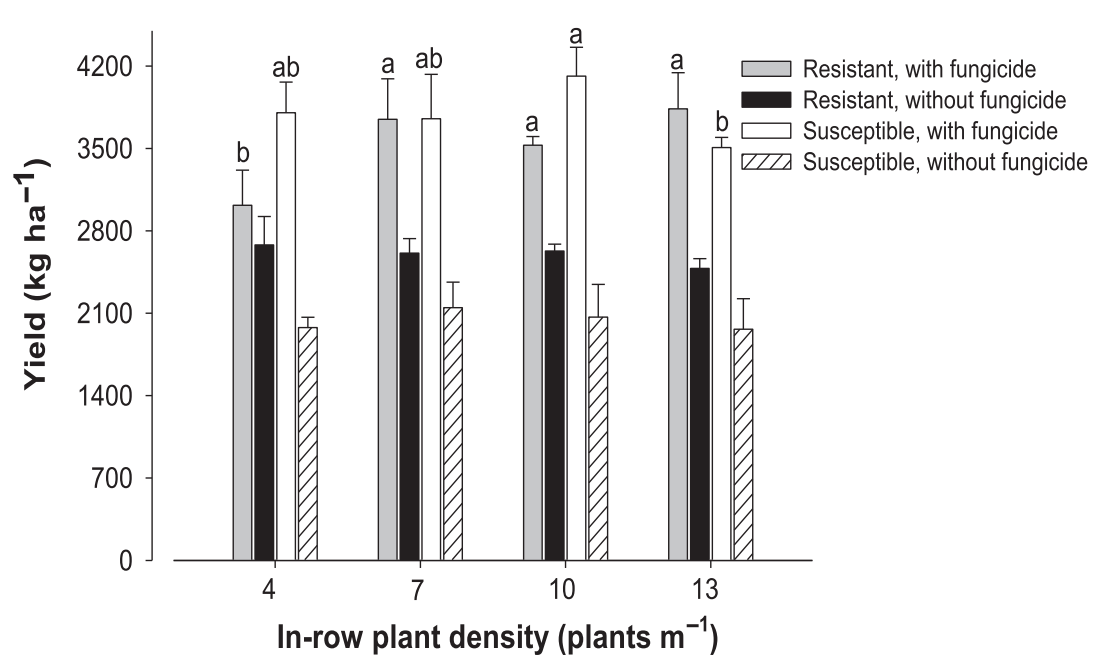

Figure 6 Common bean line (partially resistant $=$ CNFC 10720, susceptible $=$ VC 6$) \times$ in-row plant density $\times$ fungicide interaction on yield $(n=4)$ in Oratórios, 2013, when white mould (Sclerotinia sclerotiorum) pressure was moderate/high. In either the white or the grey bars, means with the same letter do not differ significantly by Duncan's test at $5 \%$ level. Differences among means of either the black or the striped bars were nonsignificant. Error bars represent standard error of the mean.

tall and open canopy (Hoyos-Villegas et al., 2015) should be the target of common bean breeders in Brazil, aiming for resistance to WM. For soybean, an upright open canopy is also associated with avoidance to WM (Kim et al., 1999), but morphological traits related to avoidance mechanism are not mentioned in the literature for other crops susceptible to WM.

For both lines, 4 plants $\mathrm{m}^{-1}$ decreased WM disease. However, this IRPD also decreased yield relative to the other IRPD, as revealed by the cross-site analyses performed using data from the four trials where WM occurred. In addition, 4 plants $\mathrm{m}^{-1}$ decreased yield in the absence of WM. For the resistant line, 7, 10 or 13 plants $\mathrm{m}^{-1}$ did not significantly affect WMI, WMSI and yield in each trial individually, regardless of the fungicide levels, suggesting that the currently recommended 11-13 plants $\mathrm{m}^{-1}$ may be used for type II beans with partial resistance to WM in conventional (using fungicide) as well as in organic production systems. Advantages of 11-13 plants $\mathrm{m}^{-1}$ relative to lower IRPD include a better suppression of weeds (Liebman et al., 2004), which may increase WM severity when in high density (Pynenburg et al., 2011), a lower percentage of plants with pods touching the soil (Horn et al., 2000), and a lower risk of crop failure associated with a low percentage of seed germination or seedling death. For the susceptible line, 7 or 10 plants $\mathrm{m}^{-1}$ maximized yield in all trials, but under moderate WM pressure 7 plants $\mathrm{m}^{-1}$ may decrease WMSI more intensively than 10 plants $\mathrm{m}^{-1}$, regardless of the fungicide levels. Under moderate WM pressure, 13 plants $\mathrm{m}^{-1}$ increased both WMI and WMSI relative to lower IRPDs, independently of the fluazinam levels. In addition, under moderate/high WM pressure, 13 plants $\mathrm{m}^{-1}$ decreased yield by $15 \%$ relative to 10 plants $\mathrm{m}^{-1}$ when fluazinam was applied twice. The yield reduction caused by 13 plants $\mathrm{m}^{-1}$ only when fluazinam was applied could not be explained. These results suggest that $7-10$ plants $\mathrm{m}^{-1}$ should be used for WM-susceptible beans, especially in a conventional production system. These results support the hypothesis that the most appropriate IRPD for type II beans depends on the cultivar's reaction to WM.

For the semiprostrate type III bean, Vieira et al. (2010) found that reduction from 16 to 4 plants $\mathrm{m}^{-1}$ increased yield linearly under moderate/high or high WM pressure. In the present study, it was found that for type II beans, 4 plants $\mathrm{m}^{-1}$ may decrease yield under some conditions in the field. Probably, the efficacy of low IRPD in managing WM is higher for type III than for type II beans, because type III beans have a denser canopy and tend to lodge more (Soltani et al., 2016). IRPD $\times$ fungicide interaction was not significant for yield in the case of a semiprostrate bean (Vieira et al., 2010), but in the present study this interaction was significant for yield under low WM pressure. In addition, IRPD $\times$ fungicide $\times$ line interaction was significant for yield when WM pressure was moderate/high. The less morphological plasticity of type II plants compared to type III plants (Soltani et al., 2016) may be a factor involved in these results.

The microclimate within the type II bean canopy can be modified by plant density (Miklas et al., 2013). In fact, on average over the five trials conducted in this study, the canopy closure at R6 growth stage was reduced by $5 \%$ at 10 plants $\mathrm{m}^{-1}$ and by $27 \%$ at 4 plants $\mathrm{m}^{-1}$, in comparison with canopy closure at 13 plants $\mathrm{m}^{-1}$. However, the most appropriate IRPD for either resistant or susceptible beans should maximize yield and minimize WM development under different WM pressures. One strength of this study was the five-variable situation of WM pressure (absent, low, low/moderate, moderate and moderate/high) in which the data were collected. These five WM pressures are the most common situations observed in the autumnwinter season in Brazil. 

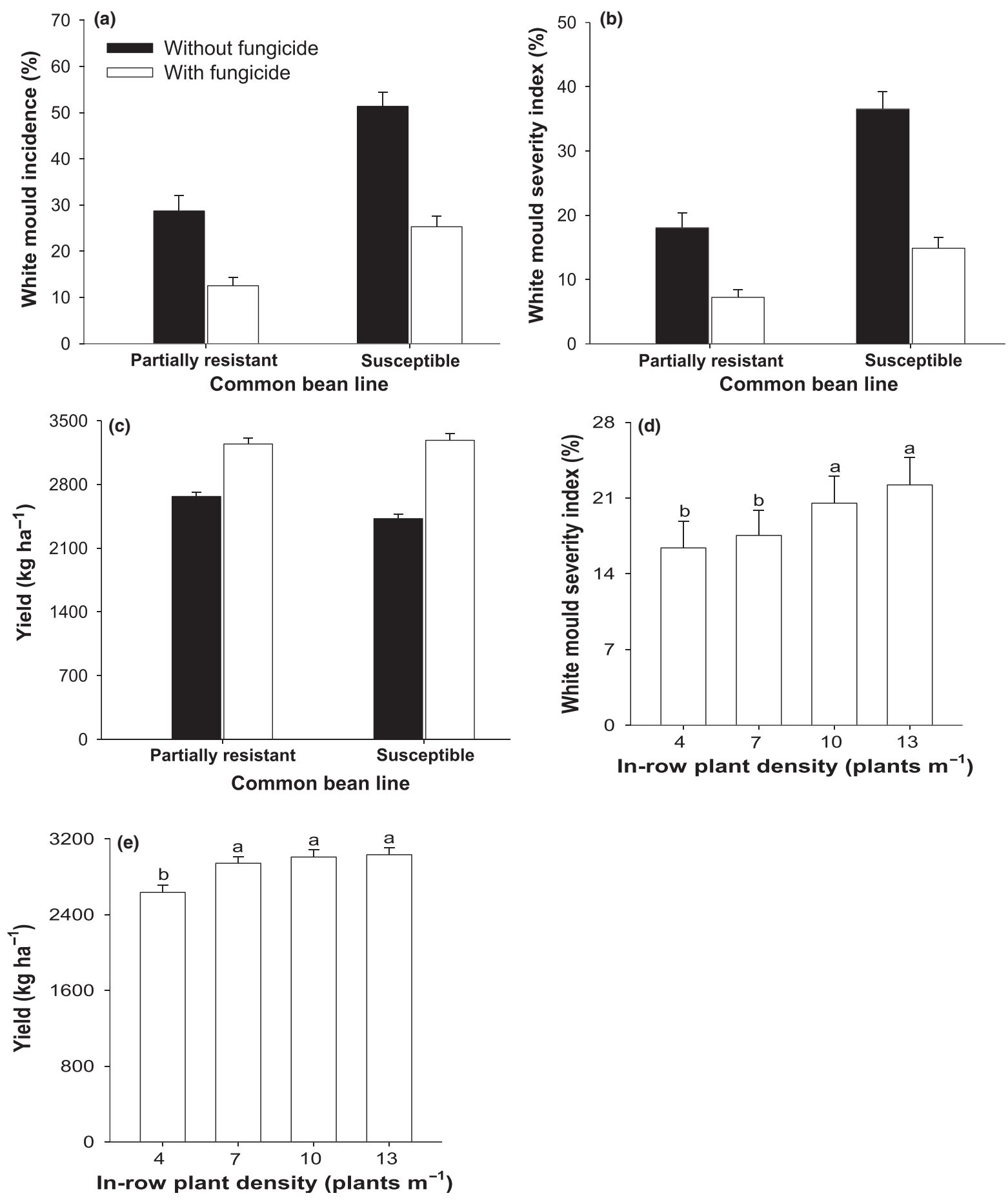

Figure 7 Results from a cross-site analysis for the four trials where white mould (Sclerotinia sclerotiorum) occurred. Common bean line (partially resistant $=$ CNFC 10720, susceptible $=$ VC 6) $\times$ fungicide interaction on white mould incidence (a), white mould severity index (b) and seed yield (c) averaged across in-row plant density $(n=64)$. Effects of in-row plant density on white mould severity index (d) and yield (e) averaged across line and fungicide $(n=64)$. Means with the same letter do not differ significantly by Duncan's test at $5 \%$ level. Error bars represent standard error of the mean.

Several foliar fungicides are known to be effective against WM. However, fluazinam is the industry standard (Mahoney et al., 2014) and offers consistent white mould control (Vieira et al., 2010; Pynenburg et al., 2011; Mahoney et al., 2014). Timing application is also an important aspect of WM control with 
fungicide. The first fungicide application should be made at the onset of flowering to protect senescing petals and damaged tissue against ascospore infection (Caesar \& Pearson, 1983). The results of all five trials indicate that fluazinam increased yield by between $13 \%$ and $57 \%$. Additionally, fluazinam reduced angular leaf spot severity in the three trials in which this disease occurred. In Coimbra, where fluazinam increased yield by $16 \%$, WM was absent and angular leaf spot severity was low. One possible effect of fluazinam in Coimbra would be the fungicide-induced 'greening effect', but it was not observed. Thus, fluazinam provided other benefits to plants that were not identified. It could be argued that, due to the unknown benefits provided by fluazinam, yield would be increased by $13 \%$ (the lowest magnitude of yield increment caused by fluazinam in this study). Based on that premise, the increase in yield caused by fluazinam in WM management alone could be estimated as ranging from zero (under low WM pressure) to $41 \%$ (under moderate/high WM pressure). Fluazinam may also control anthracnose (Vieira et al., 2010). In Brazil, farmers using irrigation generally use broad-spectrum fungicides for foliar diseases (especially angular leaf spot and anthracnose) control before the onset of flowering. The fungicide azoxystrobin was used with this purpose in the present study. Thus, plants of all plots were sprayed with azoxystrobin approximately 20 days before the onset of flowering, and they were sprayed again 8-11 days later. It is believed that azoxystrobin had little or no effect on WM development because this fungicide was applied before flowering and, most importantly, in vitro results with azoxystrobin against S. sclerotiorum growth were not encouraged (McMillan et al., 1999).

Saindon et al. (1993) found no effects of IRPD or IRPD $\times$ between-row spacing interaction on WMI and yield of a composite of selected navy bean lines with type II growth habit. Following this study, Saindon et al. (1995) tested the relative ability of three type II beans to avoid WM at four IRPD (from 5.7 to 13.8 plants $\mathrm{m}^{-1}$ ) in a constant between-row spacing of $0.23 \mathrm{~m}$. Even in this narrow row planting, the highest levels of WM infection occurred only at IRPD greater than 10.3 plants $\mathrm{m}^{-1}$. Results from these two studies indicate that type II beans may be grown at high IRPD without greatly increasing the incidence of WM. Results of the present study using a resistant line support this claim, but results obtained with a susceptible line do not. These results associated with those of Saindon et al. (1993, 1995) offer a possibility, in further research, to test type II beans with resistance to WM using a combination of IRPDs (including 13 plants $\mathrm{m}^{-1}$ or even higher) with between-row spacings narrower than $0.5 \mathrm{~m}$, because according to Ziviani et al. (2009), association of narrow between-row spacing and high in-row plant density may increase yield of type II beans.
This study suggests that when type II beans known to have partial field resistance to WM are cultivated in areas infested with $S$. sclerotiorum, the use of the currently recommended 11-13 plants $\mathrm{m}^{-1}$ does not increase WM disease in plants and does not affect yield even when WM pressure is moderate/high. For cultivars susceptible to WM, 7-10 plants $\mathrm{m}^{-1}$ ensures fewer WM symptoms in plants and maximizes yield for most of the WM pressure conditions. The results of this study may lead farmers and agronomic consultants to a more precise recommendation of in-row plant density for type II beans.

\section{Acknowledgements}

R.F.V., T.J.P.J. and M.S.L. thank the Conselho Nacional de Desenvolvimento Científico e Tecnológico (CNPq) for their research fellowships. This study was supported by Fundação de Amparo à Pesquisa do Estado de Minas Gerais (Fapemig).

\section{References}

Alvares CA, Stape JL, Sentelhas PC, 2014. Köppen's climate classification map for Brazil. Meteorologische Zeitschrift 22, 711-28.

Caesar AJ, Pearson RC, 1983. Environmental factors affecting survival of ascospores of Sclerotinia sclerotiorum. Phytopathology 73, 1024-30.

Conab, 2018. Acompanhamento da safra Brasileira. Grãos. v. 5 Safra 2017/18 - Sexto levantamento. Brasília, Brazil: Companhia Nacional de Abastecimento. [https://www.conab.gov.br/component/k2/item/d ownload/15232_d62544f1a7acc13bfc0a332a9d0fc576]. Accessed 5 May 2018

Ender M, Kelly JD, 2005. Identification of QTL associated with white mold resistance in common bean. Crop Science 45, 2482-90.

Hall R, Phillips LG, 1996. Evaluation of parameters to assess resistance of white bean to white mold. Annual Report of the Bean Improvement Cooperative 39, 306-7.

Horn FL, Schuch LOB, Silveira EP et al., 2000. Spacing and plant population for dry bean harvest mechanization. Pesquisa Agropecuária Brasileira 35, 41-6.

Hoyos-Villegas V, Mkwaila W, Cregan PB et al., 2015. Quantitative trait loci analysis of white mold avoidance in pinto bean. Crop Science 55, 2116-29.

Kane MV, Grabau LJ, 1992. Early planted, early maturing soybean cropping system: growth, development and yield. Agronomy Journal 84, 769-73.

Kim HS, Sneller CH, Diers BW, 1999. Evaluation of soybean cultivars for resistance to sclerotinia stem rot in field environments. Crop Science 39, 64-8.

Kolkman JM, Kelly JD, 2002. Agronomic traits affecting resistance to white mold in common bean. Crop Science 42, 693-9.

Lehner MS, Paula Júnior TJ, Teixeira H et al., 2011. Reaction of common bean genotypes after inoculation of plants with Sclerotinia sclerotiorum. Annual Report of the Bean Improvement Cooperative 54, 136-7.

Liebman M, Mohler CL, Staver CP, 2004. Ecological Management of Agricultural Weeds. Cambridge, UK: Cambridge University Press.

Lima RC, Lehner MS, Paula Júnior TJ et al., 2013. Physiological resistance to Sclerotinia sclerotiorum in common bean lines in the state of Minas Gerais, Brazil. Annual Report of the Bean Improvement Cooperative 56, 49-50.

Lima RC, Teixeira PH, Souza AFF et al., 2015. Partial resistance to white mold among common bean elite lines developed in Brazil. Annual Report of the Bean Improvement Cooperative 58, 57-8. 
Mahoney KJ, McCreary CM, Gillard CL, 2014. Response of dry bean white mould [Sclerotinia sclerotiorum (Lib.) de Bary, causal organism] to fungicides. Canadian Journal of Plant Science 94, 905-10.

McMillan RT, Graves WR, Vande Hei RL, 1999. Potential new chemistry for the control of Sclerotinia sclerotiorum. Annual Report of the Bean Improvement Cooperative 42, 61-2.

Miklas PN, Porter LD, Kelly JD, 2013. Characterization of white mold disease avoidance in common bean. European Journal of Plant Pathology 135, 525-43.

Miklas PN, Kelly JD, Steadman JR, 2014. Registration of pinto bean germplasm line USPT-WM-12 with partial white mold resistance. Journal of Plant Registrations 8, 183-6.

Pascual A, Campa A, Pérez-Vega E et al., 2010. Screening common bean for resistance to four Sclerotinia sclerotiorum isolates collected in northern Spain. Plant Disease 94, 885-90.

Paula Júnior TJ, Vieira RF, Rocha PRR et al., 2009. White mold intensity on common bean in response to plant density, irrigation frequency, grass mulching, Trichoderma spp., and fungicide. Summa Phytopathologica 35, 44-8.

Pynenburg GM, Sikkema PH, Robinson DE, 2011. The interaction of annual weed and white mold management systems for dry bean production in Canada. Canadian Journal of Plant Science 91, 587-98.

Ramalho MAP, Abreu AFB, Guilherme SR, 2014. Informações Técnicas para o Cultivo do Feijoeiro-Comum na Região Central Brasileira: 2015-2017. Lavras, Brasil: Fundecc, 73-4.

Ribeiro Júnior JI, 2001. Análises Estatísticas no SAEG. Viçosa, Brasil: Editora UFV.

Saindon G, Huang HC, Kozub GC, 1993. Incidence of white mold and yield of upright bean grown in different planting patterns. Journal of Phytopathology 137, 118-24.

Saindon G, Huang HC, Kozub GC, 1995. White-mold avoidance and agronomic attributes of upright common beans grown at multiple planting densities in narrow rows. Journal of the American Society for Horticultural Science 120, 843-7.

van Schoonhoven A, Pastor-Corrales MA, 1987. Standard System for the Evaluation of Bean Germplasm. Cali, Colombia: CIAT.
Schwartz HF, Singh SP, 2013. Breeding common bean for resistance to white mold: a review. Crop Science 53, 1832-44.

Singh SP, Terán H, Lema M et al., 2007. Registration of white mold resistant dry bean germplasm line A 195. Journal of Plant Registrations 1, 62-3.

Soltani A, Bello M, Mndolwa E et al., 2016. Targeted analysis of dry bean growth habit: interrelationship among architectural, phenological, and yield components. Crop Science 56, 3005-15.

Teixeira PH, Souza AFF, Silva PML et al., 2018. Performance in field of common bean genotypes selected for partial resistance to white mold. Annual Report of the Bean Improvement Cooperative 61, 165-6.

Vieira RF, Paula Júnior TJ, Teixeira H, 2010. White mold management in common bean by increasing within-row distance between plants. Plant Disease 94, 361-7.

Vieira RF, Paula Júnior TJ, Carneiro JES, 2012. Management of white mold in type III common bean with plant spacing and fungicide. Tropical Plant Pathology 37, 95-101.

Viteri DM, Otto K, Terán H et al., 2015. Use of four Sclerotinia sclerotiorum isolates of different aggressiveness, three inoculation per plant, and delayed multiple evaluation to select common beans with high levels of white mold resistance. Euphytica 204, 457-72.

Ziviani AC, Ribeiro Júnior WQ, Ramos MLG et al., 2009. Spatial arrangements for common beans with different architecture and their effects on yield and plant covering. Bioscience Journal 25, 1-9.

\section{Supporting Information}

Additional Supporting Information may be found in the online version of this article at the publisher's web-site.

Table S1. The effects of location/year (trial), in-row plant density (IRPD), common bean breeding line, fungicide, and their interactions on white mould incidence (WMI), white mould severity index (WMSI), and seed yield in the four trials where plants were infected by Sclerotinia sclerotiorum. 